\title{
EFEKTIFITAS PENGEIMBANGAN BAHAN AJAR ILMU PENDIDIKAN ISLAMI BERBASIS MODEL PEIMBELAJARAN KOOPERATIF TIPE JIGSAW MELALUI KEGIATAN DESIMINASI PADA STAIS DDI MAROS
}

\author{
Bahraeni \\ Staf Jurusan PAI FTK UIN Alauddin Makassar
}

\begin{abstract}
This research is the result of research of development of teaching materials of Islamic education which is done through dissemination activity with problem How is the effectiveness level of the utilization of teaching materials of Islamic education in STAIS DDI Maros? The goal is to describe the level of effectiveness of the use of teaching materials of Islamic education that has been developed based on jigsaw type cooperative learning model. The effectiveness level of development of teaching materials of Islamic education based on jigsaw type cooperative learning model through the dissemination activity of normalized gain value equal to 0.77 high category. The response of lecturers to the modules and other learning tools obtained the average value of 3.80 categories is very good. Student response to the module and other learning tools obtained the average value of 3.71 categories is very good. The activity of lecturers to manage the learning obtained the average value of 3.90 categories is very good, and student activity obtained the average value of 1.68 with the category of very active students follow the learning process.
\end{abstract}

Keywords: Teaching Material Development, Jigsaw Cooperative Learning Model, Islamic Education Science

\section{A. Pendahuluan}

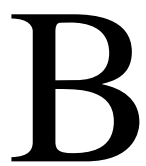
ahan ajar merupakan bahan materi pembelajaran (instructional materials) yang berisi tentang pengetahuan, keterampilan, dan sikap yang dipelajari peserta didik dalam rangka mencapai standar kompetensi yang telah ditentukan. Secara teori, bahan ajar dapat meningkatkan produktivitas pembelajaran, memungkinkan pembelajaran yang bersifat individual, memberikan dasar yang lebih ilmiah tentang pembelajaran, dan memungkinkan belajar seketika (Ramayulis, 2014: 178).

Bahan ajar pada dasarnya sebuah bahan yang didesain secara spesifik untuk keperluan pembelajaran. Bahan ajar juga merupakan seperangkat materi yang disusun secara sistematis sehingga tercipta lingkungan atau suasana yang memungkinkan peserta didik belajar dengan baik. Pentingnya bahan ajar dalam proses pembelajaran sudah tidak diragukan lagi. Fauzan mengatakan bahwa bahan ajar adalah merupakan bagian dari proses pembelajaran antara guru dan murid (Fauzan, 2005: 2).

Dalam proses pembelajaran kedudukan bahan ajar sangat penting, karena dengan bahan ajar akan terdapat manfaat bagi pendidik dan peserta didik. Bagi pendidik, 
manfaat bahan ajar di antaranya menghemat waktu mengajar, menempatkan pendidik sebagai fasilitator, menciptakan suasana pembelajaran yang efisien dan interaktif. Bagi peserta didik, manfaat bahan ajar dapat mendorong kemandirian belajar, memperluas waktu belajar karena kapanpun mereka dapat belajar yang penting ada kemauan untuk belajar.

Salah satu model pembelajaran yang mendapat perhatian besar oleh para pendidik adalah model pembelajaran koperatif. Model ini bukanlah hal baru bagi para guru dan dosen. Para guru dan dosen telah menggunakannya selama bertahun-tahun dalam bentuk kelompok laboratorium, kelompok tugas, kelompok diskusi, dan sebagainya. Namun, penelitian terakhir di Amerika Serikat dan beberapa negara lain telah menciptakan metode pembelajaran koperatif yang sistematis dan praktis yang ditujukan untuk digunakan sebagai elemen utama dalam pola pengaturan di kelas. Pengaruh penerapan metode ini sekarang telah didokumentasikan, dan telah diaplikasikan pada kurikulum pengajaran yang lebih luas (Slavin, 2005: 9). Model ini sekarang telah digunakan secara intensif dalam tiap subjek pendidikan, mulai taman kanak-kanak sampai perguruan tinggi dengan ciri khas yang tersendiri.

Ilmu Pendidikan Islam merupakan kajian ilmu pendidikan yang berdasarkan Islam. Isi dari ilmu ini adalah kumpulan teori-teori tentang pendidikan berdasarkan ajaran Islam. Namun demikian, tidak hanya sebatas kumpulan teori, tetapi juga penjelasan tentang teori, dan data yang mendukung pelaksanaan teori itu (Tafsir, 2014: 12).

Ilmu Pendidikan Islam sebagai mata kuliah kehususan ilmu tarbiyah, wajib diberikan pada seluruh mahasiswa Juru Tarbiyah STAIS DDI Maros. Hasil wawancara awal peneliti terhadap seorang dosen pengampu mata kuliah ilmu pendidikan Islam pada Jurusan Tarbiyah STAIS DDI Maros (Drs. H. Muh. Latif, M.Pd.I) menyatakan bahwa "Bahan atau materi ilmu pendidikan Islam pada perguruan tinggi ini belum memiliki buku sumber yang dijadikan pegangan utama yang sesuai sistematika materi berdasarkan kurikulum.” Kenyataan lain, dampak pembelajaran ilmu pendidikan Islam pada Juru Tarbiyah STAIS DDI Maros, belum tercapai secara maksimal. Hal ini ditandai dengan adanya beberapa mahasiswa yang tidak mencapai nilai 75 berdasarkan kriteria ketuntasan minimal hasil UAS.

Dengan melihat fenomena seperti di atas, maka peneliti memandang perlu melakukan kegiatan inovatif dalam kegiatan pembelajaran ilmu pendidikan Islam dengan cara melakukan penelitian pengembangan bahan ajar yang berbasis penerapan model koperatif tipe jigsaw.

\section{B. Rumusan Masalah}

Permasalahan penelitian ini adalah "Bagaimana tingkat efektifitas penerapan bahan ajar ilmu pendidikan Islam melalui kegiatan desiminasi pada Jurusan Tarbiyah STAIS DDI Maros?” 


\section{Kajian Teiretis}

\section{Teori Bahan Ajar}

Bahan ajar atau learning materials merupakan istilah yang sering digunakan dalam pembelajaran. Bahan ajar ini mencakup alat bantu visual seperti handout, slides/overheads, yang terdiri atas teks, diagram, gabar dan foto, plus media lain seperti audio, video, dan animasi (Davie dan Hington, 2006: 130).

Menurut Dick dan Carey, 2009 dalam Yaumi, bahan ajar juga sering diistilahkan bahan pembelajaran, yakni "instructional materials" mencakup seluruh bentuk-bentuk pembelajaran seperti petunjuk bagi instruktur, modul peserta didik, overhead tranparances (OHP), videotapes, format multi media berbasis computer, dan web pages untuk pendidikan jarak jauh (Yaumi, 2013: 170).

Selain instructional material, learning materials, Kitao dan Kitao, 2009 dalam Yaumi, 2012 memandang bahwa bahan pembelajaran juga sering diistilahkan teaching materials, yakni dipandang sebagai materi yang disediakan untuk kebutuhan pembelajaran mencakup buku teks, video dan audio tapes, software comuter, dan alat bantu visual (dalam Yaumi, 2012: 171).

Menurut National Centre for Competency Based Training (2007) dalam Depdiknas, bahan ajar adalah segala bentuk bahan yang digunakan untuk membantu guru atau instruktur dalam melaksanakan proses pembelajaran. Bahan yang dimaksudkan dapat berupa bahan tertulis maupun tidak tertulis (Depdiknas, 2008: 7).

Pandangan dari ahli lainnya mengatakan bahwa bahan ajar adalah seperangkat materi yang disusun secara sistematis, baik tertulis maupun tidak tertulis, sehingga tercipta suatu lingkungan atau suasana yang memungkinkan siswa belajar. Menurut Panen (2001) dalam Andi mengungkapkan bahwa bahan ajar merupakan bahan-bahan atau materi pelajaran yang disusun secara sistematis, yang digunakan guru dan peserta didik dalam proses pembelajaran (Prastowo, 2011: 16).

\section{Jenis-jenis Bahan Ajar}

Jenis bahan ajar dibedakan atas beberapa kriteria pengelompokan. Menurut Koesnandar, jenis bahan ajar berdasarkan subjeknya terdiri dari dua jenis antara lain: (a) bahan ajar yang sengaja dirancang untuk belajar, seperti buku, handouts, LKS dan modul; (b) bahan ajar yang tidak dirancang namun dapat dimanfaatkan untuk belajar, misalnya kliping, koran, film, iklan atau berita. Koesnandar juga menyatakan bahwa jika ditinjau dari fungsinya, maka bahan ajar yang dirancang terdiri atas tiga kelompok yaitu bahan presentasi, bahan referensi, dan bahan belajar mandiri (Kusnandar, 2008: 12).

Berdasarkan teknologi yang digunakan, Direktorat Pembinaan Sekolah Menengah Atas, mengelompokkan bahan ajar menjadi empat kategori, yaitu bahan ajar cetak (printed) antara lain handout, buku, modul, lembar kegiatan siswa, brosur, leaflet, wallchart, foto/gambar, dan model/maket. Bahan ajar dengar (audio) antara lain kaset, radio, piringan hitam, dan compact disk audio. Bahan ajar pandang dengar (audio 
visual) seperti video compact disk, dan film. Bahan ajar multimedia interaktif (interactive teaching material) seperti CAI (Computer Assisted Instruction), compact disk (CD) multimedia pembelajaran interaktif dan bahan ajar berbasis web (web based learning material), (Depdiknas, 2008: 11).

\section{Model Pembelajaran KooperatifTipe Jigsaw}

Model Jigsaw merupakan adaptasi dari teknik teka-teki Elliot Aronson (1978). Jigsaw dalam bahasa Inggris diartikan gergaji ukir, dan ada juga yang menyebutnya dengan istilah puzzle yaitu sebuah teka-teki menyusun potongan gambar (Rusman, 2014: 217). Dalam teknik ini, mahasiswa bekerja dalam anggota kelompok yang sama, yaitu empat orang dengan latar belakang yang berbeda, seperti latar belakang kemampuan, jenis kelamin, dan latar belakang etnik. Para mahasiswa ditugaskan membaca bab, buku kecil, atau materi lain yang bersifat penjelasan terperinci lainnya. Tiap anggota tim ditugaskan secara acak untuk menjadi "ahli" dalam aspek tertentu dari tugas membaca tersebut (Slavin, 2005: 14).

Pada dasarnya, model ini dosen membagi satuan informasi yang besar menjadi komponen-komponen lebih kecil. Selanjutnya dosen membagi mahasiswa ke dalam kelompok kooperatif yang terdiri dari empat orang. Tiap orang bertanggungjawab terhadap penguasaan setiap komponen atau subtopik yang ditugaskan dosen. Langkahlangkah pembelajarannya dapat dilakukan sebagai berikut: (a) Mahasiswa dikelompokkan dalam empat anggota tiap tim; (b) Tiap mahasiswa dalam tim diberi bagian materi yang berbeda; (c) Tiap mahasiswa dalam tim diberi bagian materi yang ditugaskan; (d) Anggota dari tim yang berbeda yang telah mempelajari bagian/subbab yang sama, bertemu dengan kelompok baru (kelompok ahli) untuk mendiskusikan subbab mereka; (e) Setelah selesai diskusi sebagai tim ahli, tiap anggota kembali ke kelompok asal, dan bergantian mengajar teman satu tim mereka tentang subbab yang mereka kuasai, dan tiap anggota lainnya mendengarkan dengan sungguh-sungguh; (f) Tiap tim ahli mempresentasikan hasil diskusi; (g) Pendidik memberi evaluasi; dan (h) Penutup, dosen menutup pembelajaran (Komalasari, 2011: 65).

Memperhatikan langkah-langkah di atas, Budimansyah dan Komalasari (2009) mengillustrasikan dalam gambar sebagai berikut: 


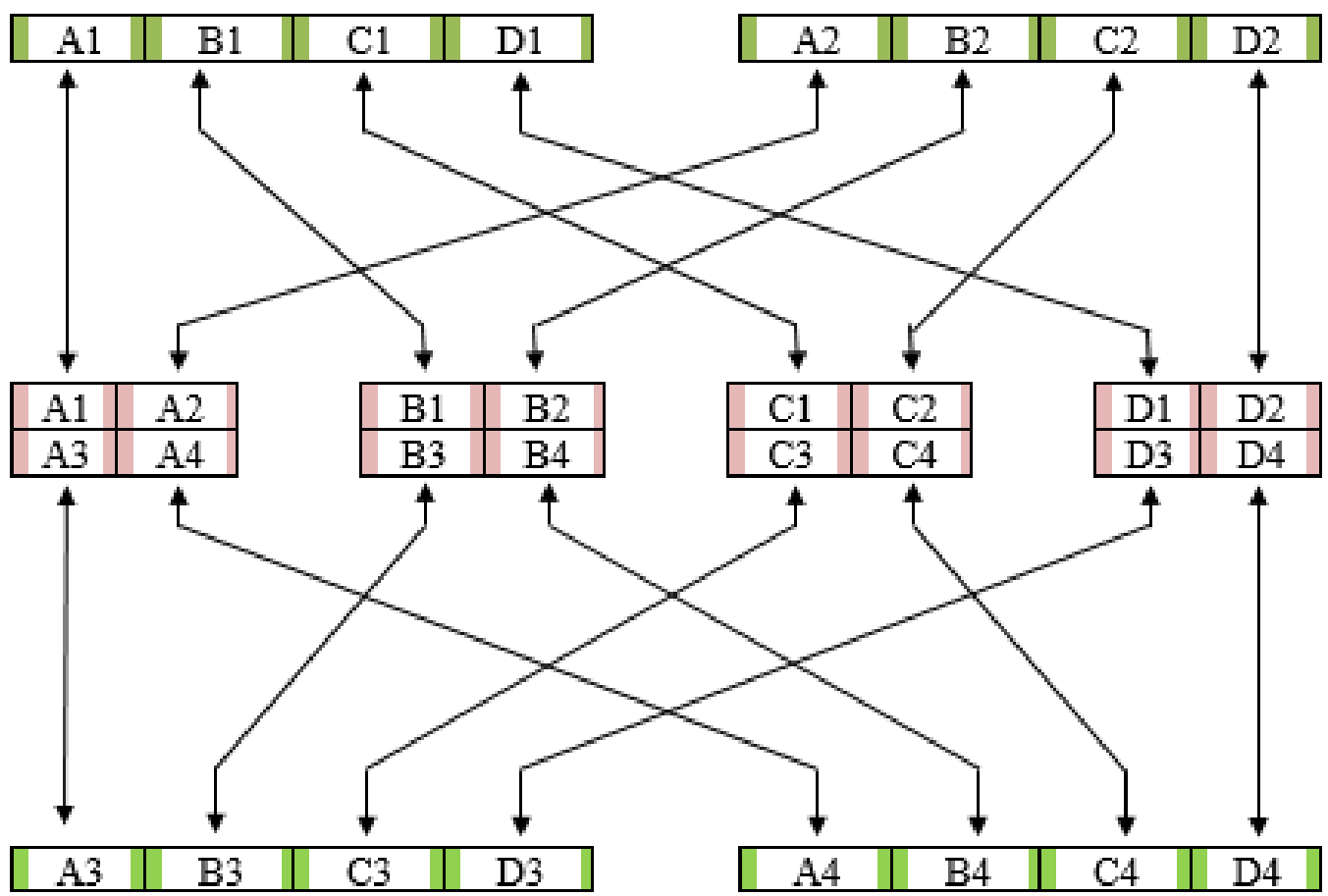

Gambar 1. Posisi Mahasiswa dalam Model Jigsaw

Gambar 1 di atas melukiskan bentuk gergaji, dimana kegiatan mahasiswa dibagi menjadi tiga tahapan. Tahap I, masing-masing anggota mendapatkan tugas tersendiri dan tugas itu menjadi tanggungjawabnya dalam hal penguasaan. Tahap II, masingmasing anggota tim bertemu dengan kelompok lain, berdasarkan kesamaan tugas. Mereka saling berdiskusi satu sama lainnya, dan hasil diskusi itulah yang dapat melahirkan tim ahli. Tahap III, tim ahli kembali ke kelompok asalnya, dan mereka menyampaikan informasi mutakhir tentang materi pembelajaran yang dipelajari pada pertemuan itu. Dengan demikian, terjadilah proses pembelajaran yang sifatnya kooperatif dengan penekanan pembelajaran yang menunjukkan sebuah norma, bahwa sesungguhnya belajar itu penting, berharga, dan menyenangkan.

\section{Ilmu Pendidikan Islam}

Pada dasarnya Ilmu Pendidikan Islam adalah ilmu pendidikan yang berdasarkan ajaran Islam. Jika dikatakan sebagai ilmu, maka isinya adalah teori, seperti isi ilmu bumi adalah teori tentang bumi. Dengan demikian, isi Ilmu Pendidikan Islam adalah teori-teori tentang pendidikan berdasarkan ajaran Islam. Namun demikan, tidaklah isi ilmu itu hanya terbatas pada kumpulan teori, masih ada isi lain dalam bentuk penjelasan teori, dan data yang mendukung penjelasan itu (Tafsir, 20014: 12).

Ilmu Pendidikan Islam sebagai ilmu, memandang bahwa manusia harus dididik melalui proses pendidikan yang Islami, berdasarkan Al-Qur'an, Hadis, dan pemikiran akal manusia (Tafsir, 2014: 22). Umat Islam meyakini bahwa kehidupan tidak dapat 
diserahkan seluruhnya kepada kemampuan akal, atau kepada kemauan manusia, baik secara pribadi maupun secara keseluruhan manusia. Tidak sama dengan pandangan humanisme yang mengajarkan bahwa akal manusia telah mencukupi untuk mengatur dunia dan kehidupan manusia secara totalitas. Akan tetapi, umat Islam selalu melihat kehidupan manusia di dunia harus ditopan oleh ketiga hal di atas, yaitu wahyu Allah swt (Al-Qur'an), penjelasan wahyu (Hadis), dan hasil ijtihad (pemikiran logis) manusia.

Ilmu Pendidikan Islam (IPI) merupakan kajian mengenai kependidikan yang mempunyai peranan penting untuk dipelajari setiap muslim, yang berkeinginan agar pendidikan dapat berlangsung secara baik untuk mencapai tujuan pembentukan pribadi manusia berdasarkan nilai-nilai Islam (Soleha dan Rada, 2011: 8).

Epistemologi pengembangan Ilmu Pendidikan Islam membahas dasar dan wilayah pengembangan Ilmu Pendidikan Islam itu sendiri, yakni berisi teori-teori tentang pendidikan dan pengajaran dalam kaitannya dengan pengembangan pendidikan Islam. Bahasannya meliputi teori-teori tentang pendidikan dan pengajaran yang menjadikan Al-Qur'an sebagai ide dasar dalam pengembangan-nya (Basri dan Saebani, 2010: 9).

Islam sebagai agama mengandung tuntutan komprehensif, membawa sistem nilai yang dapat menjadikan manusia dapat menikmati hidup dalam situasi dan kondisi, ruang, dan waktu yang receptil (tawakal) tehadap kehendak pencita-Nya, yaitu Allah swt (Arifin, 2008: 6). Situasi dan kondisi, ruang, dan waktu dimaksud mengarahkan manusia dapat menghayati dan mengamalkan ajaran-ajaran Islam, karena sebuah keyakinan dan hasil olah pemikiran bahwa untuk mendapatkan kebahagiaan hidup dapat diraih melalui nilai-nilai Islam yang terpatri pada kehidupan nyata bagi seorang muslim.

Islam memiliki sifat universal dan kosmopolit dapat merambah kepada kehidupan apa pun, termasuk pada ranah pendidikan, ketika Islam di jadikan sebagai paradigma ilmu pendidikan paling tidak berpijak pada tiga alasan yaitu: (1) ilmu pendidikan sebagai ilmu humaniora tergolong ilmu normatif, karena ia terkait oleh norma-norma tertentu. Pada taraf ini nilai-nilai Islam sangat berkompeten untuk dijadikan norma dalam ilmu pendidikan; (2) dalam menganalisis masalah pendidikan, para ahli selama ini cenderung mengambil teori-teori falsafah pendidikan barat. Falsafah pendidikan barat lebih bersifat sekuler yang kemudian memisahkan berbagai dimensi kehidupan, sedangkan masyarakat Indonesia lebih bersifat religius. Atas dasar itu, nilai-nilai ideal Islam sangat memungkinkan untuk di jadikan acuan dalam mengkaji fenomena pendidikan; dan (3) dengan menjadikan Islam sebagai paradigma maka keberadaan ilmu pendidikan memilih ruh yang dapat menggerakkan kehidupan spritual dan kehidupan yang hakiki. Tampa ruh ini berarti pendidikan telah kehilangan ideologinya (Mujib dan Mudzakkir, 1998: 32).

Lebih lanjut Mujib dan Mudzakkir melihat Islam sebagai paradigma ilmu pendidikan, memiliki desain konstruksi sistem pendidikan yang berdasarkan atas nilainilai universal Islam. Bangunan sistem ini tentunya berpijak pada prinsip-prinsip hakiki, yaitu prinsip al-tauhid, prinsip kesatuan makna kebenaran dan prinsip kesatuan sumber 
sistem. Dari prinsip-prinsip tersebut selanjutnya di turungkan elemen-elemen pendidikan sebagai world view Islam (pandangan dunia Islam) terhadap pendididkan (Mujib dan Mudzakkir, 1998: 32).

Sejarah telah membuktikan, bahwa kemunculan pendidikan sebagai disiplin ilmu yang mandiri sesungguhnya berasal dari para pemikir nonmuslim. Melalui metode empirisnya, mereka telah menemukan konsep dan teori pendidikan, sehingga mereka banyak memberikan konstribusi bagi berbagai disiplin ilmu lain yang berhubungan dengan pendewasaan manusia. Hal-hal yang mereka lakukan sebenarnya merupakan pemahaman terhadap Sunnah Allah swt yang berkaitan dengan perilaku manusia, meskipun asumsi yang digunakan berlandaskan hukum alam. Di satu sisi, upaya mereka itu merupakan pengenjawantahan dari Firman Allah swt dalam Q.S. Fushshilat (41): 53 sebagai berikut:

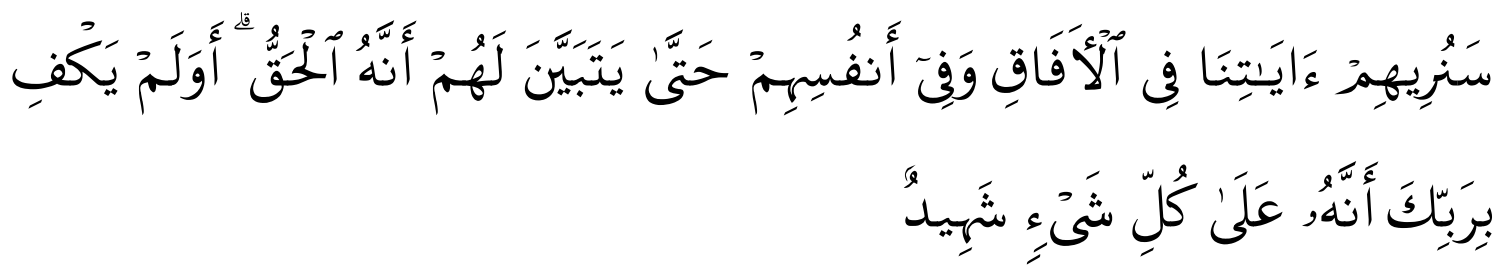

Terjemahnya:

Kami akan memperlihatkan kepada mereka tanda-tanda [kekuasaan] kami di segenap ufuk dan pada diri mereka sendiri [anfus], sehingga jelaslah bagi mereka bahwa AlQur'an itu adalah benar. Dan apakah Tuhanmu tidak cukup [bagi kamu] bahwa sesungguhnya Dia menyaksikan segala sesuatu (Kemenag., 2010: 482).

Memperhatikan ayat di atas sesungguhnya para pemikir Barat, mereka telah mempelajari ayat-ayat afaq dan anfus, sebagai fenomena alam. Namun di sisi yang lain, upaya mereka perlu mendapatkan penyucian (tazkiyah), dari yang netral etik menjadi yang sarat ideologis, melalui proses Islamisasi pendidikan.

\section{Metode Penelitian}

Penelitian ini merupakan tindaklanjut dari penelitian sebelumnya, yakni penelitian pengembangan bahan ajar ilmu pendidikan Islam berbasis model pembelajaran kooperatif tipe jigsaw, dengan merujuk pada teori model pengembangan Model Thiagarajan dan Semmel (1974). Model ini dikenal dengan nama model 4-D (four the models), yakni model yang memiliki empat tahap pengembangan. Keempat tahap dimaksud, yaitu: (1) define (pendefinisian); (2) design (perancangan); (3) tahap develop (pengembangan); dan (4) disseminate (penyebaran).

Untuk menguji tingkat efektifitasnya penerapan bahan ajar melalui kegiatan deminasi maka peneliti menggunakan analisis deskriptif frekuensi Gain Ternormalisasi dengan cara: (a) Menghitung besar skor rerata standar deviasi, median, modus, varians, rentang nilai minimum dan maksimum dengan menggunakan bantuan software SPSS 20.0 for windows; (b) Melakukan analisis Gain Ternormalisasi hasil belajar ilmu 
pendidikan Islam sebelum dan setelah pembelajaran MKI-IPI dengan menggunakan rumus rumus gain ternormalisasi (Sumber: Huke, Richard, R. 1999:2) dengan rumus:

$$
\text { Nilai Gain }=\frac{\text { Postest-Pretest }}{\text { Jumlah skor maksimum-Pretest }}
$$

Selanjutnya dibuat kategorisasi peningkatan hasil belajar dengan gain ternormalisasi adalah $\mathrm{g}>0,70$ (tinggi), $0,70 \geq \mathrm{g}>0,30$ (sedang), dan 0,30 $\geq \mathrm{g}$ (rendah).

\section{E. Hasil Penelitian}

Keefektifan pengembangan bahan ajar ilmu pendidikan Islam berbasis model pembelajaran kooperatif tipe jigsaw melalui kegiatan uji coba dan desiminasi dilihat dari aspek hasil belajar, aktivitas pembelajaran, respon dosen dan mahasiswa terhadap bahan ajar modul dan seluruh perangkat pembelajaran lainnya berdasarkan hasil analisis data dipandang sangat efektif. Hal ini dilihat dari rerata nilai gain ternormalisasi diperoleh nilai rerata 0,77 kategori tinggi. Respon dosen terhadap modul dan perangkat pembelajaran lainnya diperoleh nilai rerata 3.80 kategori sangat baik. Respon mahasiswa terhadap modul dan perangkat pembelajaran lainnya diperoleh nilai rerata 3.71 kategori sangat baik. Aktivitas dosen mengelola pembelajaran diperoleh nilai rerata 3,90 kategori sangat baik, dan aktivitas mahasiswa diperoleh nilai rerata 1,68 dengan kategori mahasiswa termasuk sangat aktif mengikuti proses pembelajaran.

\section{F. Pembahasan}

Pengembangan bahan Ajar ilmu pendidikan Islam melalui kegiatan desiminasi dipandang efektif untuk meningkatkan hasil belajar mahasiswa. Hal ini didukung oleh:

1. adanya modul dosen dan modul mahasiswa yang tersedia sebagai hasil pengembangan;

2. modul tersebut telah diteliti secara mendalam oleh pakar dan praktisi (sebagai tim validator) pengembangan bahan ajar;

3. kemahiran dosen menggunakan modul karena dilatih sebelum menggunakannya;

4. keterlibatan mahasiswa terlihat secara aktif melalui kegiatan pembelajaran; dan

5. nilai mahasiswa setelah diuji tes hasil belajar mereka dinyatakan tuntas secara klasikal, walaupun masih terdapat 2 orang yang masih memerlukan kegiatan remedial.

Respon dosen dan mahasiswa terhadap bahan ajar modul melalui kegiatan desiminasi mendapatkan respon positif. Hal ini didasarkan oleh hasil olah data melalui angket yang telah dijawab oleh dosen dan mahasiswa. Hal ini dimungkinkan karena, di samping hal di sebutkan di atas, juga karena dosen dan mahasiswa terlihat keaktifannya bersama sesuai scenario pembelajaran yang telah dipersiapkan sebelumnya. 


\section{F. Kesimpulan}

1. Pengembangan bahan ajar ilmu pendidikan Islam berbasis model pembelajaran kooperatif tipe jigsaw pada Juru Tarbiyah STAIS DDI Maros Makassar merujuk pada tahapan teori model pengembangan Model Thiagarajan dan Semmel (1974). Model ini dikenal dengan nama model 4-D (four the models), yakni model yang memiliki empat tahap pengembangan. Keempat tahap dimaksud, yaitu: (1) define (pendefinisian); (2) design (perancangan); (3) tahap develop (pengembangan); dan (4) disseminate (penyebaran).

2. Berdasarkan hasil analisis uji kevalidan melalui penilaian para ahli dan praktisi diperoleh percentage of agreements $\geq 3,5$ dan nilai tersebut dinyatakan dalam kategori sangat valid. Keefektifan pengembangan bahan ajar ilmu pendidikan Islam berbasis model pembelajaran kooperatif tipe jigsaw melalui kegiatan uji coba dan desiminasi dilihat dari aspek hasil belajar, aktivitas pembelajaran, respon dosen dan mahasiswa terhadap bahan ajar modul dan seluruh perangkat pembelajaran lainnya berdasarkan hasil analisis data dipandang sangat efektif. Hal ini dilihat dari rerata nilai gain ternormalisasi diperoleh nilai rerata 0,77 kategori tinggi.

\section{DAFTAR PUSTAKA}

Arifin, M. Ilmu Pendidikan Islam: Tinjauan Teoretis dan Praktis berdasarkan Pendekatan Interdisipliner. Jakarta: Bumi Aksara, 2008.

Basri, Hasan dan Beni Ahmad Saebani. Ilmu Pendidikan Isla. Jilid II; Bandung: Pustaka Setia, 2010.

Davies, Butcher dan Hington, Designing Learning. published in the Taylor \& Francis eLibrary, 2006.

Depdiknas, Panduan Pemgembangan Bahan Ajar, 2008, tersedia di http:// smpn1pasarkemis.files.wordpress.com diakses pada tanggal 21 Oktober 2016.

Fauzan, Ahmad. Implementasi Perangkat Pembelajaran. Jurnal Pembelajaran, 28 nomor 1, (2005).

Kementerian Agama RI. Al-Qur'an Tajwid dan Terjemahnya dilengkapi dengan Asbabun Nuzul dan Hadis Shahi. Bandung: Sygma, 2010.

Kumalasari, Kokom. Pembelajaran Kontekstual: Konsep dan Aplikasi. Bandung: Refika Aditama, 2011.

Kumalasari, Kokom. Pembelajaran Kontekstual: Konsep dan Aplikasi. Bandung: Refika Aditama, 2011.

Kusnandar, Pengembangan Bahan Ajar berbasis Webb (Online) (2008, h. 12) http:// www.teknologipendidikan.net diakses tanggal 5 Oktober 2016. 
Mujib dan Muzakkir. Ilmu Pendidikan Islam. Jakarta: Kencana Prenada Media, 1998.

Prastowo, Andi. Panduan Kreatif Membuat Bahan Ajar Inovatif: menciptakan metode Pembelajaaran yang menarik dan menyenangkan. Yogyakarta: Diva Press, 2011.

Ramayulis. Metodologi Pendidikan Agama Islam. Cet. I; Jakarta: Kalam Mulia, 2014.

Ranjit, Kumar. Research Methodology. London: Sage Publications, 2012.

Slavin, Robert. Cooperative Learning: teori, riset dan praktik. Bandung: Nusa Media, 2005.

Rusman. Model-Model Pembelajaran: Mengembangkan Profesionalisme Guru. Jakarta: Rajawali Pers, 2014.

Tafsir, Ahmad. Ilmu Pendidikan dalam Persfektif Islam. Bandung: Remaja Rosdakarya, 2014.

Thiagarajan, S. Semmel, DS. Semmel, M. Instructional Development for Training Teachers of Exceptional Children. A Sourse Book. Blomimgtn: central for innovation on teaching the handicapped, 1974.

Yaumi, Muhammad. Prinsip-Prinsip Desain Pembelajaran (Jakarta: Kencana Prenadamedia Group, 2013. 